\title{
Obituaries
}

\section{Kalvyn Schoeman van Eeden}

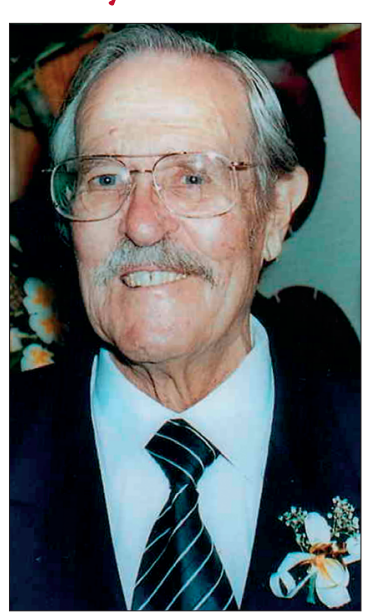

Kalvyn van Eeden died on 12 April 2012 at the age of 82 of cancer that he bravely faced with dignity, but also with a realistic and scientific approach. He was a legend in his lifetime and contributed immensely to the community and medical profession, especially in the Limpopo Province (formerly Northern Transvaal).

Kalvyn was born on 28 February 1930 in the small Karoo town of Jansenville, where he spent his childhood with his siblings and cousins, among them the great South African businessman and entrepreneur, Dr Anton Rupert. The Van Eedens and Ruperts remained close friends for the rest of their lives. At school he was a brilliant pupil, matriculating at the age of 16. He qualified MB BCh in 1952 from the Witwatersrand Medical School and was in rural general practice in the Bewaarkloof area for 3 years.

He married Marina van Niekerk from the Transvaal Lowveld in 1957 and they were happily married for 55 years. The couple left for the UK soon after their marriage. Kalvyn worked at various hospitals in England, including Taplow Hospital, where he pursued his interest in rheumatic diseases, and eventually became a member of the Royal College of Physicians, Edinburgh. He returned to South Africa and was a registrar at Groote Schuur Hospital for three years. He then entered private practice in Pietersburg, Northern Transvaal, fulfilling a great need as a dedicated and compassionate specialist physician who earned the love and respect of his patients and colleagues.

He was an associate founder of the College of Medicine, Surgery and Obstetrics and Gynaecology in 1971 and also a founder of the Soutpansberg Branch of the Medical Association of South Africa (erstwhile MASA) in 1961. He also served a term as president of the branch in 1971 and was a branch councillor for an uninterrupted period of 46 years! He retained an academic approach, kept abreast of new medical developments and maintained a lifelong appreciation of literature, poetry and an interest in non-medical science. Kalvyn was always intrigued by science - and physics in particular. He had a passion for animals, and was a successful cattle farmer, because of his scientific approach and also to a great extent due to Marina's valuable input! The couple were also staunch supporters of the Association of People with Disabilities over a period of more than 50 years.

His specialist practice spanned 48 years and he retired through ill-health on 15 April 2011 owing to mesothelioma, ostensibly related to asbestos exposure for 3 years while working as a district surgeon in the mid-1950s.

Kalvyn was an illustrious son of the Karoo, a fine gentleman, a talented doctor, an honest man, a loyal and an inspirational head of his extended family and a much loved husband, father and grandfather. He is survived by his wife Marina, their three children Frederik, Karin and Vasti, and four grandchildren, Reenen, Renò, Marina and Amelie.

\section{Christian Martin Kruger}

\section{Abraham Leib (Lampy) Maresky}

The medical fraternity of Cape Town has been bereft of an exceptional physician and respected colleague. Abraham Leib Maresky, popularly and affectionately known as Lampy by one and all, died of postoperative complications on 2 July 2012.

Reared in the schooling of those legendary teachers of traditional clinical medicine during the period popularly referred to at the University of Cape Town Medical School as the 'Forman years', but nevertheless having kept abreast of the most technical advances in medicine of the current era, he earned the respect of his colleagues as the complete physician.

Lampy was born in Kimberly on 9 April 1932, and attended the Kimberly High School where he excelled at Latin, maths, and physical science. Influenced by his older brother he chose to pursue a medical career. He enrolled at UCT in 1949 and graduated MB ChB in $1954 . \mathrm{He}$ obtained the Physics Medal in 1949 and the Anatomy Medal in 1950. He served his internship at Groote Schuur Hospital, and left for the United Kingdom in 1959, where he achieved his MRCP, having worked at the Hammersmith Hospital. He was made a Fellow of the Royal College of Physicians for the work he had done during the years he spent in the UK. He returned to Cape Town in 1961 and served as a registrar on a rotational basis, inter alia in the firms of legendary clinicians and teachers such as Frankie Forman, Jack Brock, Len Eales, Helen Brown, and the formidable Isaac Grayce. During this period he also attended at the outpatients department at Woodstock Hospital. In 1964 he opened rooms at the old Medical Centre on the Foreshore and ultimately moved to the City Park Hospital, later to be re-named the Christiaan Barnard Memorial Hospital. He regularly attended medical outpatients at Groote Schuur Hospital, while also tutoring fourth-year students, and was invited to examine fourth- and final-year students. In recognition of his contribution to clinical medicine, Lampy received the Distinguished Physicians Award.

With advancing years he retired from these various commitments, and devoted himself entirely to his private practice at Christiaan Barnard Memorial Hospital.

Lampy was a dedicated doctor, practising holistic medicine in its truest sense. In his report-back letters he meticulously detailed the patient's clinical problems, but also included the patient's family dynamics and background, relevant to the context of the illness. He embodied the truism expressed by the doyen of clinical medicine, Sir William Osler, who stated, 'The good physician treats the disease: the great physician treats the patient who has the disease'. It is also said that the qualities of a good doctor include clinical skills, communication skills, and availability. Lampy was always available day or night when called upon by his colleagues to assist with difficult medical problems. Remuneration was not his priority, and it was known that he would waive his fees when attending to the indigent. Nevertheless, every patient received his diligent and dedicated attention.

Lampy was not only a dedicated doctor but also a most affable and engaging personality. How well do I recall Lampy regaling us with some of his more humorous experiences during his Groote Schuur days, and his mimicking the odd behaviour and mannerisms of some of his more eccentric chiefs. We will miss those special occasions.

Lampy married Cynthia Lewis in 1965. They have three sons. The couple were always very proud of their Jewish heritage, and named their sons after those iconic leaders in Jewish history, Jonathan, Gideon and Saul, who garnered their strengths in times of adversity. The medical fraternity expresses its deepest sympathy to Cynthia and 